\title{
KOMUNIKASI POLITIK ANIES BASWEDAN MELALUI SOSIAL MEDIA TWITTER
}

\author{
Ashari Sakti Alim 1, Dian Eka Rahmawati ${ }^{2}$ \\ Magister Ilmu Pemerintahan, Fakultas Pascasarjana, Universitas Muhammadiyah \\ Yogyakarta ${ }^{1}$ \\ Program Studi Ilmu Pemerintahan, Fakultas Ilmu Sosial dan Ilmu Politik, \\ Universitas Muhammadiyah Yogyakarta ${ }^{2}$ \\ Email: asharisaktialim@gmail.com
}

\begin{abstract}
Abstrak
Tulisan ini ingin menganalisis bagaimana Anies Baswedan dalam menyampaikan komunikasi politiknya di sosial media Twitter. Pada era kontemporer ini salah satu komunikasi politik yang paling dominan adalah media sosial, dimana komunikasi politik sangat memegang peranan penting karena bisa berdampak untuk partisipasi politik, sosialisasi politik. Dalam bidang politik peran media sosial media sangat penting karena berkontribusi sebagai keterbukaan dan transparansi, Anies Baswedan adalah salah satu aktor politik yang bermain sosial media Twitter untuk menyampaikan komunikasi politik sekaligus menaikan popularitasnya. Sesuai dengan janji politiknya terdahulu yaitu transportasi terintegrasi dan program oke oce. Anies tak jarang menyampaikan dan memperlihatkan perkembangan janji politiknya yang telah berjalan di sosial media Twitter miliknya. dalam penyebaran informasi melalui sosial media Twitter sudah terbukti sangat efektif karena banyak penggunanya diseluruh dunia. Penelitian ini menggunakan metode penelitian kualitatif deskriptif dan melakukan analisis dengan menggunakan bantuan aplikasi perangkat lunak NVIVO12 Plus. Hasil dari ini penelitian ini mengungkapkan bahwa komunikasi politik Anies Baswedan di sosial media Twitter sangat befokus pada pelayanan publik di DKI Jakarta. Komunikasi politik dari Anies Baswedan juga mendapatkan banyak respon dari pengikutnya di akun Twitter hal ini dapat dilihat dari jumlah Retweet dan mentions yng dilakukan kepada Anies Baswedan. Anies Baswedan juga cukup aktif dalam menyampaikan komunikasi politiknya melalui sosial media Twitter seperti memberitahukan program kerja, Branding politik, memberikan perbincangan politik yang sifatnya ringan dan juga terkait dengan pelayanan publik di DKI Jakarta.
\end{abstract}

Kata Kunci : Komunikasi Politik, Anies Baswedan, Sosial Media, Twitter

\begin{abstract}
This paper wants to analyze how Anies Baswedan conveyed his political communication on Twitter social media. In this contemporary era, one of the most
\end{abstract}


dominant political communications is social media, where political communication plays an important role because it can have an impact on political participation, political socialization. In the political field the role of social media is very important because it contributes as openness and transparency, Anies Baswedan is one of the political actors who play social media Twitter to convey political communication while increasing its popularity. In accordance with its previous political promises of integrated transportation and ok oce program. Anies is not uncommon to convey and show the development of political promises that have been running on his Twitter social media. in disseminating information through social media Twitter has proven to be very effective because many users around the world. This study uses descriptive qualitative research methods and analyzes using the help of NVIVO12 Plus software applications. The results of this study revealed that Anies Baswedan's political communication on Twitter social media was very focused on public services in DKI Jakarta. Political communication from Anies Baswedan also received a lot of responses from his followers on his Twitter account. This can be seen from the number of retweets and mentions done to Anies Baswedan. Anies Baswedan was also quite active in conveying his political communication through Twitter social media such as notifying work programs, political branding, giving political talks that were light in nature and also related to public services in DKI Jakarta.

Keywords : Political Communication, Anies Baswedan, Social Media, Twitter

\section{PENDAHULUAN}

Pada era modern ini kemajuan akan teknologi komunikasi telah menyebar pada kehidupan umat manusia. Salah satu bentuk kemajuan teknologi komunikasi adalah media baru atau yang di kenal dengan teknologi digital yang kemudian melahirkan media sosial (social media). Dengan adanya kehadiran media sosial juga mempengaruhi bidang politik. Penelitian yang dilakukan di Amerika Serikat menunjukkan bahwa media sosial adalah alat kampanye yang efektif. Sebelum era media sosial, politisi di Negeri Paman Sam sudah memanfaatkan internet untuk media berkampanye (Anshari, 2016).

Di Amerika Serikat lembaga pemerintahan dan para elite politik menggunakan sosial media secara masif untuk berinteraksi dengan dan untuk menginformasikan warga negaranya atas suatu kebijakan yg telah dibuat (Nurmandi, 2015). Dan juga di Amerika Serikat penggunaan media sosial mendorong kampanye presiden amerika waktu itu Barack Obama melalui sosial media twitter @BarackObama di tahun 2008. Penggunaan akan media digital 
telah mengubah hubungan antara warga dan pemerintah dalam hal interaksi dan intensitas. Media sosial, produk dari revolusi teknologi informasi, memiliki interaksi sosial yang sangat unik dan interaktif serta intens di antara keduanya.

Sementara itu partai politik di Indonesia juga sudah banyak yang memiliki akun Facebook, Twitter, dan YouTube, disamping website resmi parpol. Sementara para elite politik atau politisi juga memiliki masing-masing akun pribadi seperti politisi Prabowo Subianto (twitter @ prabowo), Gubernur Jawa Barat Ridwan Kamil (twitter @ridwankamil), Gubernur DKI Jakarta Anies Baswedan (twitter @aniesbaswedan), Bahkan akun twitter Presiden RI Jokowi Widodo (twitter @jokowi). berstatus verified account, yang artinya sudah mendapatkan verifikasi dari pihak Twitter. Dari sosial media Twitter para tokoh politik dapat memberitahukan program kerja, pendapat mengenai isu terkini, atau pembicaraan-pembicaraan yang sifatnya ringan, menanggapi mention dari masyarakat, adalah hal-hal yang umumnya tercantum dalam linimasa Twitter para tokoh politik tersebut.

Komunikasi politik ialah proses penyampaian informasi mengenai politik dari pemerintah kepada masyarakat dan dari masyarakat kepada pemerintah, Makna komunikasi politik disini sudah bukan hal yang baru bagi dunia politik ataupun disiplin ilmu komunikasi. Komunikasi politik disini menurut (Djuyandi, 2017) yaitu sebuah gabungan yang lebih dari dua disiplin ilmu akademik kedalam suatu aktivitas, terutama dalam ada hubungannya yang terkait dengan komunikasi dan politik. Tersedianya komunikasi politik paling sering terjadi di media sosial maupun di media cetak, untuk dari itu media sosial mempunyai peran penting dalam sistem politik dan suksesnya komunikasi politik sangat akan berpengaruh pada pemantapan politik.

Komunikasi politik memiliki beberapa tujuan. Anwar arifin ada 4 tujuan dari komunikasi politik. Pertama, membangun dan membentuk citra dan opini publik; kedua, mendorong partisipasi politik; ketiga, memenangi pemilihan; keempat, mempengaruhi kebijakan negara atau publik. Keempat hal tersebut harus berjalan karena penting demi terciptanya masyarakat yang adil dan sejahtera 
(Arifin, 2015). Komunikasi politik merupakan jalan mengalirnya informasi melalui masyarakat dan melalui berbagai struktur yang ada dalam sistem politik.

Pada buku kuasa media di Indonesia yang ditulis oleh (Ross Tapsell, 2017) mencoba mengungkapkan kalau kasus yang ada di Indonesia sangat pas digunakan untuk mencari tau bagaimana media digital bisa mempengaruhi orng banyak. Pada saat yang bersamaan kekuatan media juga berpatisipasi bergerak dengan masif, orang Indonesia tergolong sebagai pengguna media sosial paling aktif se-dunia. Sebesar 70 persen populasi dari jumlah penduduk di Indonesia berada di bawah usia 35 tahun, yang sebagian besarnya memakai media sosial setiap harinya. Bahkan 64 juta penduduk di Indonesia memakai facebook pada tahun 2015, menduduki peringakat ke empat tertinggi di dunia. Sementara itu ada 20 juta penduduk Indonesia yang memiliki akun twitter, menduduki peringkat tiga tertinggi di dunia. uniknya jakarta adalah kota yang dijuluki sebagai kota paling aktif di twitter, dengan sebagian besar tweet per hari dikirim dari kota ini.

E-Government mengacu pada penggunaan TIK untuk meningkatkan efisiensi fungsi internal dan proses pemerintahan (Twizeyimana \& Andersson, 2019) Misalnya, e-government menghubungkan berbagai departemen dan lembaga, sehingga membuat arus informasi lebih cepat dan lebih mudah di antara departemen pemerintah yang berbeda. kebutuhan untuk menggunakan TIK untuk meningkatkan hubungan antara warga negara dan negara, dengan implikasi untuk proses demokrasi dan struktur pemerintah.

Pemilihan Anies Baswedan sebagai tokoh politik yang diteliti dikarenakan akhir-akhir ini Anies Baswedan menjadi topik pembicaraan di khalayak masyarakat banyak dan juga ramai diperbincangkan di media sosial khususnya Twitter. Seperti kasus dimana Anies yang posisinya sekarang sebagai Gubernur DKI Jakarta dinilai berhasil mengatasi banjir dan menurunkan kemacetan di kota jakarta, bahkan Anies diprediksi akan maju sebagai calon presiden pada pemilihan yang akan datang. Anies Baswedan, Gubernur DKI Jakarta saat ini memiliki followers mencapai 3,3 juta pengikut di akun sosial media twitter ini cukup aktif memaikan akun milik pribadi. dipilihnya Twitter disebabkan Anies Baswedan sering menyapa dan sering menerima keluh kesah masyarakat kota jakarta di akun 
sosial media Twitter miliknya. Karena menurut Anies sendiri media sosial twitter memudahkannya untuk berkomunikasi dengan masyarakat khususnya mengenai pelayanan publik (Khalila Khairunnisa, 2018)

Penelitian pada Twitter Anies Baswedan ini dimulai dari bulan April tahun 2014 sejak Anies Baswedan masih menjabat sebagai Menteri Pendidikan dan Kebudayaan. Akun Twitter milik Anies Baswedan memang sudah resmi terdaftar di Twitter pada bulan februari tahun 2010, akan tetapi pada tahun tersebut Anies Baswedan belum aktif dalam menggunakan Twitter, Anies mulai aktif dan intens dalam berinteraksi di sosial media Twitter terhitung sejak tahun 2014. Pada era yang sudah sangat modern ini sangat di butuhkan seorang pemimpin yg inovatif dan kreatif. Pemimpin yang bisa di katakan berhasil bisa di ukur dengan dengan bagus atau tidaknya stabilnya perekonomian rakyat, pembagunan infrastruktur pembagunan dan adanya tingkat kesejahteraan di daerah tersebut. Dan yang paling penting dari dari Anies Baswedan adalah gaya berkomunikasi politik, kepemimpinan yang kuat dan tegas dan memiliki karakter tersendiri pada saat ini menjabat sebagai Gubernur DKI Jakarta.

Pada awal tahun 2013, Anies Baswedan masuk ke dalam dunia politik setelah sebelumya mendalami dunia sosial dan pendidikan. Anies pernah menjadi peserta konvensi capres dari partai demokrat. Tetapi pada tahun 2014 anies resmi bergabung dengan dengan tim pemenang Joko Widodo-Jusuf Kalla. Sesudah Jokowi-JK terpilih sebagai Presiden dan Wakil Presiden pada tahun 2014, Anies kemudian ditunjuk oleh Jokowi sebagai Menteri Pendidikan dan Kebudayaan (Dzaky, 2019). Beberapa tahun kemudian Anies Baswedan di usung oleh partai gerindra untuk maju sebagai calon Gubernur DKI Jakarta. Anies yang di pasangkan dengan Sandiaga Salahuddin Uno ini terpilih sebagai Gubernur dan Wakil Gubernur DKI Jakarta pada tahun 2017 setelah berhasil mengalahkan pasangan Basuki Tjahaja Purnama-Djarot Saiful Hidayat dalam pilkada DKI Jakarta yang digelar dalam dua putaran. 


\section{Gambar 1.}

Akun Twitter Resmi Anies Baswedan

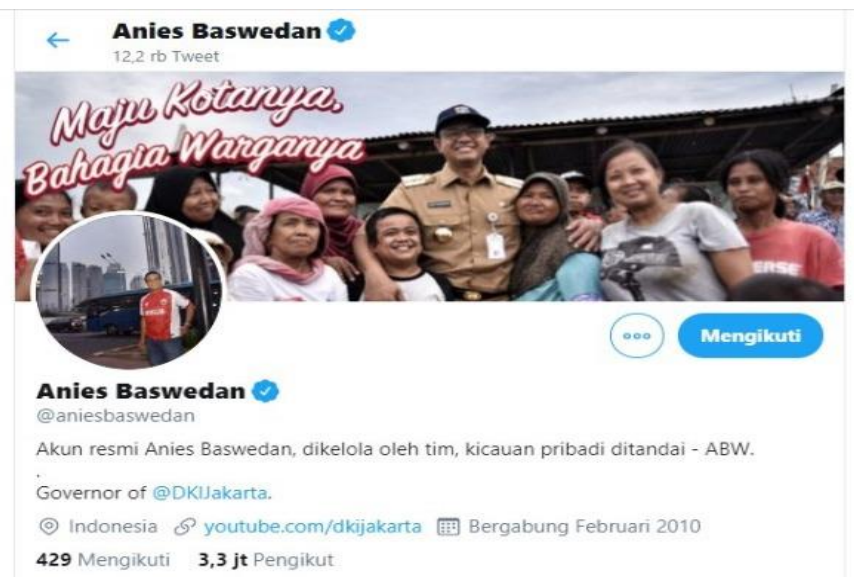

Pemimpin yang di anggap baik sangat dipengaruhi oleh bagaimana gaya berkomunikasi mereka untuk bisa menggunakan strategi mempengaruhi. Anies Baswedan merupakan orang yang benar-benar di anugrahi dengan gaya berkomunikasi yang luar biasa, hal ini karena Anies merupakan seorang Akademisi yang pada dasarnya sudah terbiasa untuk berkomunikasi di depan umum atau di forum-forum besar. Namun sayangnya gaya berkomunikasi Anies Baswedan dianggap sebagian kalangan terlalu beretorika karena dianggap strategi komunikasi retorika ini seharusnya digunakan untuk bisa mencapai tujuan bersama dan bukan untuk mengediskriminasi orang lain demi kepentingan pribadi. Akun Twitter yang terletak di @aniesbaswedan. Akun Twitter-nya yang sudah terdaftar pada tahun 2010 ini memiliki banyak pengikut sebanyak 3,3 juta pengikut, disini dapat dilihat bahwa pesan-pesan disebarluaskan atau dikirimkan oleh Anies Baswedan dengan media jejaring sosial twitter akan membaca dan dikenal oleh jutaan pengikut (Febrian anshari, 2016)

Berdasarkan penjelasan diatas, relevansi komunikasi politik yang semakin meningkat di media sosial, menyiratkan perubahan mendasar dalam komunikasi politik tradisional ke komunikasi politik yang lebih modern sehingga ada yang akan di sampaikan akan jauh lebih efektif. yang biasanya telah diprakarsai dan dikelola secara eksklusif oleh aktor-aktor politik. Oleh karena itu hal tersebut sangat menarik untuk diteliti, Twitter yang dapat digunakan untuk diskusi politik 
dan untuk memengaruhi proses pembuatan opini politik dan memberitahukan program kerja pada masyarakat.

\section{PEMBAHASAN}

Kehadiran media baru berbasis digital membuat informasi politik tidak hanya semakin masif, tetapi juga terdistribusi dengan cepat dan bersifat interaktif. Terutama sosial media twitter dengan karakteristiknya itu tidak sedikit aktor politik di sejumlah negara memanfaatkan twitter proses kampanye politik dan menyampaikan program kerja yg sedang di laksanakan maupun yang sudah selesai secara intens. (Purbohastuti, 2017).

\section{Gambar 2.}

Intensitas Aktivitas Twitter Anies Baswedan

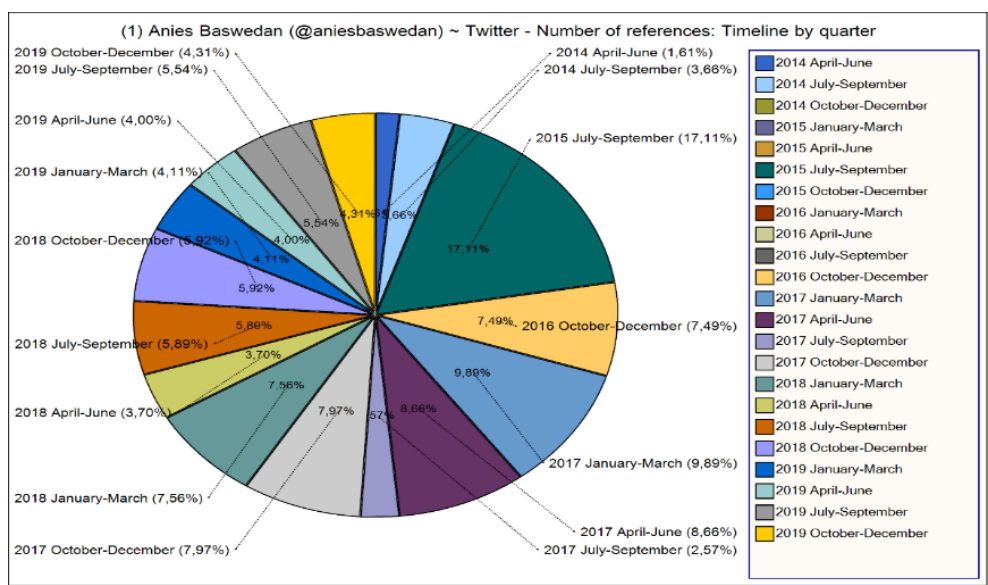

Sumber: Diolah oleh peneliti menggunakan Nvivo12plus (2020)

Twitter adalah bagian yang sangat penting dari sosial media karena membuat komunikasi politik dari para aktor politik bisa berjalan dengan efektik. Dalam data diatas diambil melalui Nvivo12 Plus yang merupakan intensitas aktivitas Twitter Anies Baswedan mulai dari tahun 2014 sampai tahun 2019. Dari index data diatas pada bulan juli sampai bulan september tahun 2015 mengalami presentase sebanyak sebesar $17,11 \%$ dalam jangka waktu bulan ini saat anies baswedan masih menjabat sebagai Menteri Pendidikan dan Kebudayaan.

Melalui Twitter, Anies Baswedan menyampaikan program kerja yang akan dia tuntaskan selama menjabat sebagai Menteri Pendidikan dan Kebudayaan, salah satunya program kerja anies yang paling ramai di bicarakan dan disoroti 
oleh netizen Twitter yaitu gerakan kampanye memuliakan guru dan berbagi kerjasama antara Kemdikbud dengan BUMN dan Swasta. Sendangkan pada bulan januari sampai bulan maret 2017, mengalami presentase sebesar 9,89\% pada bulan ini Anies Baswedan banyak berinteraraksi melalui akun Twitter miliknya untuk menyampaikan visi dan misi politiknya pada saat pencalonannya sebagai Gubernur DKI Jakarta.

Pada saat itu mendapat banyak perhatian dari Netizen adalah Anies Baswedan menjanjikan kemudahan bagi warga DKI Jakarta dengan untuk memiliki rumah dengan DP Nol Rupiah. Pada bulan April 2014 Partai Demokrat melakukan konvensi nasional untuk mencari calon Presiden dan nama Anies Baswedan masuk di dalamnya dan sesaat setelah menghadiri cara konvensi nasional partai demokrat. Penggunaan twitter Anies Baswedan, dari gambar diatas bisa dinilai bagaimana efektivitas penggunaan twitter oleh Anies Baswedan. dan Twitter sekarang sudah menjadi wadah yang efektif untuk menyampaikan program kerja atau menyampaikan informasi.

\section{Gambar 3.}

Interaksi Komunikasi Politik Anies Baswedan

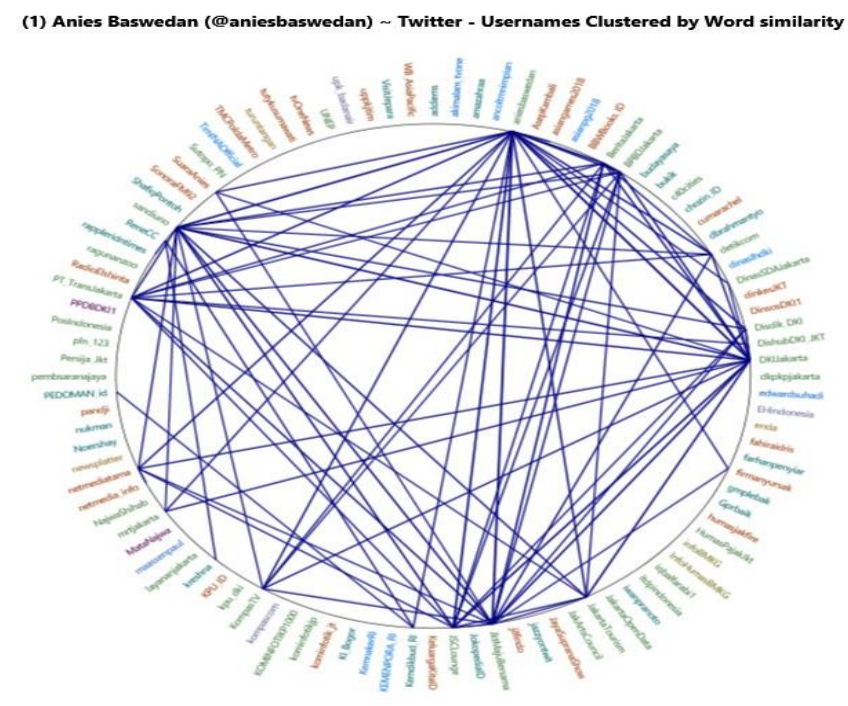

Sumber: Diolah oleh peneliti menggunakan Nvivo12plus

Berdasarkan analisis word similarity Nvivo12 Plus, bahwa @ aniesbaswedan sudah sangat aktif menyampaikan program kerja, layanan publik 
hingga komunikasi politiknya. Jika melihat pada gambar diatas, akan dapat dilihat bahwa kebanyakan komunikasi politik atau interaksi yang di lakukan oleh Anies Baswedan melalui akun Twitter miliknya @aniesbaswedan benar di fokuskan dalam hal-hal politik. Dimana interaksi yang dilakukan oleh Anies Baswedan lebih terlihat jelas pada aktor politik dan sekaligus pasangannya sebagai Gubernur dan Wakil Gubernur DKI Jakarta pada 2017 yang lalu yaitu Sandiaga Uno (twitter @ sandiuno). Selain itu juga nampak interaksi dengan lembaga pemerintah DKI Jakarta yang bergerak dibidang pelayanan publik, seperti Transportasi Jakarta (twitter @PT_Transjakarta) dan Juga Jakarta Smart City (twitter @JSCLounge). Interaksi komunikasi yang dilakukan oleh Anies Baswedan di Sosial Media Twitter lebih terlihat cenderung kearah politik dan cukup partisipatif dengan masyarakat karena dapat dilihat jumlah balasan yang dilakukan terhadap masyarakat relatif banyak.

Interaksi komunikasi politik antara Anies Baswedan dan Sandiaga Uno dimulai pada tanggal 2 juni 2017 dimana Anies membuat tweet di akun Twitter miliknya bahwa dia akan berpasangan dengan Sandiaga Uno (twitter @ sandiuno) pada pemilihan Gubernur DKI Jakarta periode 2017-2022. Pada saat itu Anies dan Sandi sama-sama berkomitmen untuk membangun Provinsi DKI Jakarta untuk menjadi lebih baik lagi. Setelah resmi dilantik sebagai Gubernur dan Wakil Gubernur DKI Jakarta, Anies dan Sandi berharap bisa mentunaikan janji-janji yang sudah pernah didengungkan oleh Anies dan juga Sandi baik saat berkampanya maupun setelah mereka di tetapkan sebagai gubernur dan wakil gubernur terpilih periode 2017-2022 dalam kontestasi Pilkada DKI Jakarta. Anies baswedan dan Sandiaga Uno juga menggaris bawahi bagaimana persiapan DKI Jakarta dalam mengatasi banjir, persoalan MRT, LRT, hal-hal soal transportasi yang sering mengakibatkan macet di Jakarta.

Anies Baswedan juga sering memperlihatkan pelayanan yang sedang dilakukan oleh pemprov DKI Jakarta melalui Twitter. selain pelayanan transportasi, Anies juga menekan pada ruang terbuka hijau melalui JakartaSmartCity (twitter @JSCLounge) dan (twitter @layananjakarta)dengan tujuan untuk menciptakan ruang dan menghidupkan suasana di kota jakarta. 
melalui Twitter Anies memberitahu bahwa pada tahun 2019 lalu Pemprov DKI Jakarta telah membangun ruang terbuka hijau (RTH) berupa taman maju bersama yang tersebar di 48 titik, lalu pada tahun 2020 ini akan dibangun 51 taman lainya. Taman maju bersama menerapkan Smart Environment dan Smart People sehingga masyarakat memiliki tempat ramah lingkungan untuk melakukan berbagai kegiatan yang menghibur dan mendidik. Selain menyediakan ruang untuk aktivitas masyarakat, taman-taman ini juga disediakan untuk mendukung program pengendalian banjir.

Partai politik yakni partai gerinda juga sering melakukan mentions terhadap Anies Baswedan di sosial media Twitter. dimana pada saat Anies Baswedan dan Sandiaga Uno bertemu kembali pasca Pilpres kemarin pada rakerda partai Gerindra di Jakarta, Hal ini membuat banyak perbincangan dan sempat menjadi tranding topik di Twitter. Selain Sandiaga Uno, aktor politik lain yang memiliki hubungan erat dengan Anies Baswedan baik di dunia nyata maupun di sosial media khususnya Twitter yaitu mantan Gubernur Jawa Barat Ahmad Heryawan. Hubungan antara Anies dan Aher sapaan akrab dari Ahmad heryawan ini dimulai pada saat Aher memberikan dukungan penuh terhadap Anies dan Sandi Uno saat maju sebagai calon Gubernur dan Wakil Gubernur pada tahun 2017 kemarin, hingga pada saat ini munculnya isu-isu yang ramai diperbincangkan di Twitter mengenai Anies yang akan maju sebagai capres dan Aher sebagai wakilnya pada pemilihan presiden yang akan datang.

Tabel 1.

Keterhubungan Twitter Anies Baswedan

\begin{tabular}{|l|l|l|l|}
\hline Username & Degree & Degree In & Degree Out \\
\hline aniesbaswedan & 228 & 0 & 228 \\
\hline DishubDKI_JKT & 9 & 9 & 9 \\
\hline sandiuno & 8 & 8 & 9 \\
\hline detikcom & 7 & 7 & 8 \\
\hline PT_TransJakarta & 7 & 7 & 8 \\
\hline netmediatama & 7 & 7 & 8 \\
\hline gerindra & 6 & 6 & 7 \\
\hline aheryawan & 5 & 5 & 7 \\
\hline kompascom & 4 & 4 & 6 \\
\hline JSCLounge & 4 & 4 & 6 \\
\hline
\end{tabular}




\begin{tabular}{|l|l|l|l|}
\hline Username & Degree & Degree In & Degree Out \\
\hline persija_Jkt & 3 & 3 & 5 \\
\hline kominfotikjp & 3 & 3 & 5 \\
\hline JktMajuBersama & 3 & 3 & 4 \\
\hline KOMINFOTIKP1000 & 2 & 2 & 4 \\
\hline dinaslhdki & 2 & 2 & 4 \\
\hline kompascom & 2 & 2 & 4 \\
\hline mrtjakarta & 2 & 2 & 3 \\
\hline
\end{tabular}

Sumber : Diolah oleh peneliti menggunakan Nvivo12 Plus, 2020

Berdasarkan data pada tabel di atas, keterhubungan Twitter Anies Baswedan masih terkait dengan pada setiap tweets dari Anies Baswedan tetang program kerja, sangat banyak mendapat respon balik seperti mentions dan Reetwet dari Netizen di twitter, tidak hanya netizen tetapi juga setiap postingan Anies Baswedan juga di mentions balik atau mendapatkan Reetwet oleh politisi, stasiun televisi swasta dan club sepak bola juga ikut me-Retweet. Komunikasi politik Anies di Twitter ini sangat menarik perhatian dari banyak kalangan karena Anies dianggap bisa menyampaikan program kerja, curhatan pribadi, pembahasan politik dan juga bisa mewakili institusinya dengan baik.

\section{KESIMPULAN}

Komunikasi politik yang dilakukan oleh Anies Baswedan melalui sosial Twitter mendapat banyak perhatian dari banyak kalangan dan juga netizen di Twitter. Intensitas dan Interaksi melalui Twitter Anies Baswedan sangat berfokus pada lingkup pelayanan publik di jakarta, hal ini dikarenakan posisi Anies sekarang yang masih aktif menjabat sebagai Gubernur DKI Jakarta, sementara itu dalam hal politik Anies belum terlalu memfokuskan pada hal tersebut, Dunia politik juga tak lepas dari pengaruh perkembangan teknologi digital dan media sosial. Media sosial ibarat dua sisi mata uang bagi para aktor politik. Di satu sisi keberhasilan memanfaatkan media sosial dapat memungkinkan aktor politik mendapatkan dukungan positif. Tapi di sisi lain kegagalan memanfaatkan media sosial berisiko merusak citra yang dia miliki, Tetapi Anies disini berhasil memaikan perannya sebagai aktor politik sekaligun mewakili pemerintah DKI jakarta dalam berkomunikasi politik melalui sosial media khususnya Twitter. 
Maka dari itu, pemilihan Twitter oleh Anies Baswedan sebagai wadah untuk menyalurkan informasi memang bisa dianggap cukup tepat mengingat pengguna Twitter di Indonesia maupun diseluruh dunia cukup tinggi. Cara berkomunikasi, cara untuk mencari berita atau menyalurkan informasi dan bahkan untuk kehidupan sosial dan politik melalui media sosial khususnya di Indonesia pada saat ini mengalami perkembangan yang sangat pesat. Para aktor politik juga sudah mulai melakukan komunikasi politik untuk mencari simpati atau melakukan branding politic melalui Twitter pada era kontemporer ini.

\section{DAFTAR PUSTAKA}

Anshari, F. (2016). Komunikasi Politik di Era Media Sosial Faridhian Anshari Staff Pengajar STT PLN Jakarta. Jurnal Komunikasi, 8(1), 91-101.

Arifin, A. (2015). Politik Pencitraan Pencitraan Politik,.

Djuyandi, Y. (2017). Komunikasi Politik Tim Pemenangan Hendra Hemeto Dalam Pemilihan Ketua Dpd Ii Partai Golkar Kabupaten Gorontalo Periode 2016-2021. Jurnal Wacana Politik, 2(1), 10-21. https://doi.org/10.24198/jwp.v2i1.11322

Dzaky, A., Yogyakarta, U. M., Azizah, A., Yogyakarta, U. M., Nugroho, D. I., \& Yogyakarta, U. M. (2019). ANIES BASWEDAN PEMIMPINAN YANG KREATIF MASA KINI, (June), 0-20.

Febrian anshari, dkk. (2016). Personal Branding of Anies Baswedan Through Facebook And Twitter Account: Study Of Image Grid Analysis in Banjarmasin Society Aged 17 - 24 Years. Journal of Government and Politics, 7(3). https://doi.org/10.18196/jgp.2016.0037

Khalila Khairunnisa. (2018). Analisis Pengaruh Efektifitas Media Sosial Twitter Terhadap Government Open Communication Dengan Pendekatan Technology Acceptance Model ( Tam ) Pada Masyarakat Bandung Analysis Influence the Effectiveness of Social Media Twitter Against Government Open Co, 5(2), 1652-1658.

Nurmandi, A. (2015). SOCIAL MEDIA USE: RETHINKING CIVIC ENGAGEMENT IN GOVERNMENT*, (August), 1-11.

Purbohastuti, A. . (2017). EFEKTIVITAS MEDIA SOSIAL SEBAGAI MEDIA PROMOSI Arum. Tirtayasa Ekonomika, 12(2), 212-231. 
Ross Tapsell. (2017). Kuasa Media Di Indonesia. jakarta: Marjin Kiri.

Twizeyimana, J. D., \& Andersson, A. (2019). The public value of E-Government - A literature review. Government Information Quarterly, 36(2), 167-178. https://doi.org/10.1016/j.giq.2019.01.001 